\title{
ПОЗИЦИЯ ПРОТЕСТАНТСКИХ ЦЕРКВЕЙ ВО ВРЕМЯ ПОЛИТИЧЕСКОГО КРИЗИСА В АРМЕНИИ
}

\begin{abstract}
Аннотация. В статье проанализирована роль протестантских иерквей в рамках политического кризиса в Армении в 2018 г. Особое внимание уделено анализу деятельности протестантской иеркви пятидесятнического направления «Слово жсизни» сквозь призму религиоведческого и политологического подходов. В статье делаются выводы о том, что протестантские иеркви евангельского направления, утвердившегося на постсоветском пространстве в 1990-х г2., активно проявляют себя в общественно-политическом пространстве, зашишщая свои интересы и развивая миссионерскую деятельность. Отличительными чертами участия нетитульных иерквей в политической жсизни является провозглашение своей приверженности патриотизму и начиональным интересам Армении, принципиальное отстаивание демократических иеенностей, целенаправленное воспитание среди верующцих гражданского самосознания и необходимости вовлечения членов иеркви в гражданскую активность, выработка стратегии молодёжной работы, которая предполагает широкое участие молодёжи и подростков в развитии гражданского общества, в общественных движениях и поли-тических акииях.
\end{abstract}

Ключевые слова: Армения, межрелигиозный диалог, христианство, протестантизм, государственно-иерковные отношения.

Среди постсоветских стран Армения отличается одним из самых высоких уровней религиозности населения и роли религиозных организаций в общественной жизни. Безусловно, наибольшим влиянием обладает Армянская апостольская церковь, и именно с этой исторической церковью страны государство и политики выстраивают отношения, с этой церковью связана важная миротворческая миссия в регионе ${ }^{1}$. Однако за прошедшие с момента распада СССР десятилетия в Армении, как и в регионе в целом укоренились представители других христианских конфессий, главным образом, протестантизма, которые стремятся отстоять своё право быть частью культуры и общества, оказывать влияние на общественно-политические процессы. В протестантской среде, в свою очередь, выделяются евангельские церкви пятидесятнического направления (или харизматы), представленные в Армении одной из самых многочисленных в странах СНГ церквей «Слово жизни». Анализ политической активности церкви позволяет понять механизмы гражданского участия религиозных организаций в жизни государства и общества в периоды политических трансформаций.

Активность самых разных христианских церквей в обществе, наличие дискуссий, включающих в себя религиозную тематику и осознание важности религии, являются значимым

(с Лункин Роман Николаевич - кандидат философских наук, ведущий научный сотрудник, руководитель Центра по изучению проблем религии и общества ИЕ РАН, заместитель главного редактора журнала «Современная Европа». Aдрес: 125009, Россия, Москва, Моховая ул., дом 11, стр. 3. Email: romanlunkin@gmail.com.

DOI: http://dx.doi.org/10.15211/vestnikieran62018182188

${ }^{1}$ Сафонов Д.В., Мельник С.В. Миротворческий потенциал межрелигиозного диалога (на примере участия религиозных лидеров в разрешении Карабахского конфликта). Коммуникология. Том 5, № 5. 2017. С. 116-135. 
элементом, определяющим степень вовлечённости религиозных организаций в политику ${ }^{1}$. Согласно опросу, проведённому в Армении в рамках «World Values Survey», 89,3\% от общего числа опрошенных армян указали на важность религии в своей жизни: 57,5\% армян указали, что религия играет очень важную роль в их жизни, ещё $31,8 \%$ считают религию для себя «скорее важной». Важной религию считают и представители молодого и среднего поколения $-88,3 \%$ в возрастной группе до 29 лет и 88,4\% в группе от 30 до 49 лет. Для сравнения, в России 41,8\% считают религию «важной» и «скорее важной», в Белоруссии 48\%, Украине $60,8 \%$, Азербайджане 69,2\%. По этим показателям Армения стоит в одном ряду с Грузией и Польшей - странами Европы с наиболее высоким уровнем религиозности: в Грузии - 97,1\% опрошенных, в Польше $-79,6 \%{ }^{2}$.

Пятидесятническая церковь «Слово Жизни» (СЖ) в Ереване является одной из крупнейших христианских общин на постсоветском пространстве. Как и многие подобные церкви, она возникла на волне зарождения харизматического нового движения в начале 1990-х гг., а возглавил движение «Слово Жизни» в Армении пастор Артур Симонян (род. В 1966 г.). В его биографии утверждается, что до 1991 г. он жил в Москве и занимался бизнесом, то есть уже в советское время стал предпринимателем, скорее всего, это означает, что он занимался торговлей. В 1988 г. он крестился в одной из церквей в Москве, в 1991 г. влился в общину «Слово Жизни» (СЖ), которая недавно появилась в Ереване. Вслед за большинством служителей Симонян поехал учиться в Библейскую школу СЖ в Уппсале в Швеции, в 1995 г. стал пастором, в 1997 г. уже основал свою собственную армянскую школу. У армянской церкви около 40 филиалов, несколько тысяч верующих в Ереване. Для маленькой Армении церковь, собирающая более тысячи человек на свои богослужения, стала настоящим явлением. Гражданская активность, которую воспитывают в церкви, поставила церковь в центр политических событий, что неожиданно в стране с господствующим положением Армянской апостольской церкви (ААЦ).

Конкуренция с ААЦ за души верующих, ревность по поводу растущего влияния церкви периодически приводили к антисектантским кампаниям в местной прессе против СЖ. К примеру, в 2012 г. в ереванских газетах писали про скандал вокруг актрисы и певицы Анжелы Саргсян - якобы она кого-то пыталась соблазнить и участвовала в разного рода похождениях, а выходить «сухой из воды» ей помогала связь с влиятельной церковью СЖ. Саргсян и правда несколько раз выступала на богослужениях СЖ, но постоянной прихожанкой не была. Симонян, которого изображали рядом с «порноактрисой» в газете, подал в суд, но суд церковь проиграла, так как все обвинения в адрес церкви и пастора были косвенными.

Между тем, СЖ в Армении переросла обычные столкновения с сектоведами из ААЦ и вышла на большую политическую сцену, также как многие протестантские церкви Украины. Свою роль сыграло, по крайней мере, три фактора общих для всех протестантских церквей: целенаправленное воспитание гражданской и социальной активности в сплочённой общине, готовность к изменениям и интуитивное чувство того, когда общество трансформируется, и национальный патриотизм.

Во время майской революции 2018 г. СЖ фактически поддержала революционные изменения в обществе и нового премьер-министра Никола Пашиняна. Церковь сразу стала вовлечена в круговорот политических событий в довольно противоречивом ключе, у СЖ появились враги, была предпринята попытка убрать церковь из публичного поля, навязав ей оди-

\footnotetext{
${ }^{1}$ Партии и движения политической альтернативы в современной Европе. [сб. статей] / [отв. ред. В.Я. Швейцер]. - М. : Ин-т Европы РАН , 2018. С. 36-54.

${ }^{2}$ Крюкова Н.В. «У нас неверующих нету!»: отношение к религии в современной Армении. Новые российские гуманитарные исследования. Номер 11.2016. С. 9.
}

Научно-аналитический вестник ИЕ РАН, 2018, №6 
озный образ «политической антиармянской секты». Что является правдой, а что вымыслом в обвинениях в отношении СЖ, до конца не понятно, но есть целый ряд фактов о её участии в политике, которые помогут хотя бы отдалённо понять роль церкви в армянской революции.

23 апреля 2018 г. с началом кризиса СЖ объявляет «Молитву за Армению» ${ }^{1}$ - обычная практика в протестантских церквях, когда происходит что-то важное в стране, то провозглашается специальная усиленная молитва. В Украине молитва за страну стала также мобилизующим фактором, своего рода призывом «думать, что делать», думать об изменениях в своей стране. Пастор Артур Симонян подчёркивал в своём заявлении: «Нет сомнений в том, что ваше высокое гражданское сознание, сердечное отношение к стране и нации заслуживают восхищения, и никто не имеет права разорвать её. Это возрождение, возрождение, Армения никогда не станет прежней».

Симонян вдохновлял людей на гражданское действие, но призывал к мирным методам: «Я признаю, что есть только призывы к миру и поощрение мирного пути борьбы. В то же время я понимаю, что эмоции и эмоции сейчас высоки, и в этих условиях важно, чтобы вы сохранили свою христианскую сущность в качестве сыновей мира, которые только должны любить людей. Пожалуйста, никогда не теряйте рассудок, и пусть в ваших сердцах царит любовь и мир Христа. Мы с вами, вместе с нашей нацией. Мы молимся, чтобы наш Небесный Отец был защитой армянского народа, и Господь благословил нашу землю».

Одной из главных тем для выступлений Артура Симоняна стала борьба с коррупцией в Армении и надежда на то, что Пашинян изменит государственную систему, сделает её более демократичной. 9 мая 2018 г. Симонян отмечал: «В последнее время в Армении произошло то, что можно назвать победой. Общественность приняла решение создать систему, которая будет бороться со всеми видами взяточничества и лжи. Конечно, это определённо победа, и везде можно встретить людей, которые приписывают победу себе. Я думаю, что правильно сказать, что в победе есть много владельцев. У меня есть следующие предложения:

1. Слава Богу.

2. Честь народам.

3. Благодарю г-на Пашиняна и его команду.

4. Молитесь бывшему правительству, которое не входило в столкновения, что могло привести к пролитию крови».

Следуя своей позиции, отдельно 19 июня 2018 г. старший пастор СЖ осудил взяточничество после ареста генерала Манвела Григоряна: «Возлюбленные, лучшая жизнь свята и праведна. Я призываю вас приблизиться к кресту Христа и жить в Его благодати перед Богом, прозрачным, чистым, без взятки».

17 мая 2018 г. Симонян уже попытался от имени церкви СЖ скорректировать продолжающиеся протесты, создать «атмосферу солидарности», которая помогла бы Пашиняну проводить свою политику: «Некоторые жалуются сразу и требуют немедленного решения своих проблем, забывая, что правительство работает неделю, даже в очень сложных условиях.... Я призываю вас избавиться от революционного духа и сплотить нашу страну». Во-первых, Симонян призвал не требовать от Пашиняна всего и сразу, а дать ему возможность поработать. Во-вторых, встал на защиту мэры Еревана, так как протестующие требовали его отставки, поскольку он состоял в Республиканской партии. Однако уже в 13 октября 2018 г. Симонян активно поддержал нового мэра - ставленника Пашиняна, Айка Марутяна, который победил

\footnotetext{
1 Здесь и далее автор в качестве источника использует официальный сайт и социальные сети церкви «Слово жизни» в Армении, блог старшего пастора церкви Артура Симоняна, а также материалы армянских информационных агентств.
}

Научно-аналитический вестник ИЕ РАН, 2018, №6 
на выборах в горсовет как лидер Альянса премьер-министра страны Николы Пашиняна. Симонян особенно отметил, что Марутян дал торжественное обещание Богу: «Я думаю, что администратор, который понимает свою ответственность не только перед людьми, но прежде всего перед Богом, будет справедливым и успешным в своей миссии». Неизвестно при этом, членом какой церкви является мэр Еревана.

Влияние церкви СЖ проявилось в том, что её члены участвовали в гражданских акциях, тем более что для этого не требовалось какого-то специального требования со стороны руководства церкви. Старший пастор и так отмечает важность быть активным гражданином и строить процветающую Армению. Как отмечала, местная пресса, консолидировано с СЖ могли выступать и другие протестантские общины «Новое поколение», «Рема» и другие. Численность их реальных активистов может насчитывать несколько тысяч - 3-5. Политолог и глава Центра за содействие демократии в Ереване Степан Даниелян отметил в интервью автору, что не только СЖ, но и другие церкви участвовали в гражданских протестах, так как у них много молодёжи.

Практическим воплощением политического влияния СЖ стали посты в правительстве и скандалы вокруг церкви. К примеру, Никол Пашинян назначил своим помощником Софью Навасардян, судя по прессе, она является личным парикмахером жены Пашиняна Анны Акопян ${ }^{1}$. Членом СЖ является управделами аппарата премьер-министра Геворг Ачемян, правда, он занимал этот пост до июля 2018 г.

После усиления СЖ почти сразу началась кампания диффамации в прессе местных сектоведов, к примеру, широко разошлось в соцсетях интервью эксперта по культовым организациям Артура Вердияна сайту Miasin.Ru, но не было приведено никаких конкретных фактов, порочащих СЖ.

Сам пастор Симонян уже 20 июля отреагировал, заявив об информационной атаке на церковь, обозначив две основные темы:

«1. Церковь Слова Жизни осуществила Бархатную Революцию,

2. Церковь «Слово Жизни» руководит движением «Новая Армения, Новый Гимн» против Католикоса».

Артур Симонян косвенно подтвердил политическую роль церкви. Он подчеркнул, что против церкви используют политтехнологи, чтобы создать «козла отпущения», нападки на церковь - это «целенаправленный удар по авторитету нынешних властей», провоцирование вражды между ААЦ и евангелистами. Участие СЖ в организации и финансировании революции Симонян назвал слухами и отметил уважение к ААЦ.

Отвечая на обвинения в непатриотизме (поводом стали, в том числе, обвинения в связях с Азербайджаном, в чём обвиняли и движение «Новая Армения, новый патриарх») Симонян 13 июля 2018 г. заявил, что многие молодые люди участвовали в четырёхдневной войне (в апреле 2016 г. в Нагорном Карабахе). Например, Саша Галстян был героически убит. Симонян приводит особо отличившихся членов церкви, служащих или служивших в армии и награждённых теми или иными наградами: 1. Ерем Мхитарян-Матагис, 2. Арут Матевосян-Неркин Гораат, Сурен Саакян, 4. Врей Григорян, 5. Мушех Хачатрян, лыжный батальон,6. Овсеп Григорян, 7. Мансурийский Давид, 8. Арам Погосян, 9. Артур Парванян, 10. Артур Карапетян, 11. Вираб Манугян, разведывательный батальон.

В сентябре церковь заявила о том, что кто-то создал поддельный сайт СЖ, где якобы церковь созывала всех на гражданские акции в поддержку Пашиняня. Распространителем дезинформации стал сайт дезинформации BlogNews и его редактор Константин Тер-Накалян. 20

\footnotetext{
${ }^{1}$ http://nv.am/iz-parikmaherov-v-pomoshhniki-premera-zachem-pashinyan-beryot-na-rabotu-sektantov/ Научно-аналитический вестник ИЕ РАН, 2018, №6
} 
сентября 2018 г. СЖ заявила, что обращается в Службу национальной безопасности Армении, чтобы найти создателей этой поддельной страницы.

В июле пастору церкви СЖ в Ереване Армену Лусяну (Симонян - глава СЖ Армении в целом) пришлось объяснять, что члены СЖ могут занимать государственные должности. А попытку связать СЖ с движением «Новая Армения, новый патриарх», которое напало на католикоса Гарегина II 6 июля 2018 г., требуя его отставки, Лусян назвал смешной и необоснованной: «Мы всегда относились с уважением к Армянской Апостольской Церкви, и дискредитация национальной церкви никогда не была нашим интересом и быть не может».

Справедливости ради надо отметить, что один косвенный факт о связи СЖ с движением против католикоса ААЦ приводился на портале https://rusarminfo.ru и издание 1in.am. Один из активистов движения Ваге Петросян, руководитель общественной организации «Лига защиты автомобилистов», соратник бывшего управделами аппарата премьер-министра Армении Геворга Ачемяна. Ваге Петросяна якобы финансировал движение «Новая Армения, новый патриарх» и является членом СЖ, что не подтверждено.

В силу растущего влияния церкви СЖ её противниками, а также врагами Пашиняна и сторонниками ААЦ (партии Гарегина) была сделана попытка дискредитации церкви, как с помощью статей в прессе, так и попыткой связать с движением «Новая Армения, новый патриарх». Противопоставить современной ААЦ, обвинить в связях с Азербайджаном, так как в этом обвиняли врагов Гарегина. Наряду с этим, стоит отметить, что реформирование ААЦ является одним из пунктов либеральной повестки дня. Целый ряд статей об этом был на портале «Религии Армении» religions.am. Вардан Джалоян писал о том, что ААЦ поддерживала «правящий класс воров» и стала одним из местных отделений Республиканской партии. Манвел Саркисян, руководитель Армянского центра стратегических и национальных исследований, отмечал, что увольнения католикоса недостаточно, а надо ААЦ делать более открытой.

Фейковый сайт СЖ с призывом активно поддерживать Пашиняна могли создать как некоторые члены СЖ, так и либеральные политтехнологи, которые явно хотели, чтобы больше членов СЖ вышли на улицы. При этом надо учитывать, что церковь СЖ от либеральных сил отличает национальный патриотизм, характерный для протестантов, а также резкое неприятие признания прав сексуальных меньшинств. Таким образом, церковь СЖ в Армении прохо-дит испытание политическими искушениями с разных сторон - нападки консерваторов и использование со стороны либералов, но СЖ имеет и свои интересы. Протестантской церкви приходится учитывать тот факт, что часть общества и исследователей противопоставляют СЖ армянской культуре и даже христианству, рассматривая такого рода церкви как источник чуждого влияния: «Несмотря на то что в РА функционирует огромное множество сектантских организаций, которые ставят под сомнение догмы Армянской апостольской церкви и основы ее проповедничества, вера армянской семьи, церкви и государства достаточна прочна и армянский народ в своем большинстве неизменно следует христианским идеям. Данное состояние можно расценить как победу христианской идеологии, которая должна побудить армянское общество объединиться и по достоинству оценить всю армянскую культуру, отказаться

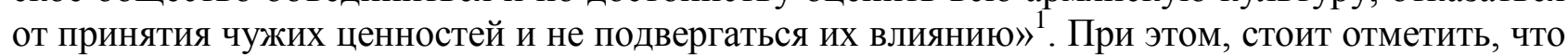
в Армении первая протестантская церковь, близкая к баптистско-евангельскому движению, появилась раньше, чем в России - в 1846 г. (Армянская Евангельская церковь) $)^{2}$.

\footnotetext{
${ }^{1}$ Мкоян Г.С. Армянская апостольская церковь, семья и государство как единая система институтов социализации и формирования социально-культурных ценностей в армянском обществе. Общество: социология, психология, педагогика. Номер 5, 2016. С. 28-30.

${ }^{2}$ Наморадзе С. Протестантизм на Кавказе. Кавказ и глобализация. Том: 2, номер 3. 2008. С. 169-180.
} 
Протестантские церкви евангельского направления, утвердившегося на постсоветском пространстве в 1990-х гг., активно проявляют себя в общественно-политическом пространстве, защищая свои интересы и развивая миссионерскую деятельность. Отличительными чертами участия нетитульных церквей в политической жизни является провозглашение своей приверженности патриотизму и национальным интересам Армении, принципиальное отстаивание демократических ценностей, целенаправленное воспитание среди верующих гражданского самосознания и необходимости вовлечения членов церкви в гражданскую активность, выработка стратегии молодёжной работы, которая предполагает широкое участие молодёжи и подростков в развитии гражданского общества, в общественных движениях и политических акциях.

\section{Список литературы}

Европа XXI века. Новые вызовы и риски: [монография] ; под общей редакцией Ал.А. Громыко, В.П. Фёдорова. - М., СПб.: Нестор-История, 2017. - 584 с.

Лункин Р.Н. Европейские церкви и демократические институты: возвращение религии или секуляризация христианства? Вестник Ленинградского государственного университета имени А.С. Пушкина. №3, 2016. С. 168-178.

Религиозные миссии на общественной арене: российский и зарубежный опыт: [коллективная моногр.] / под ред. А.А. Красикова и Р.Н. Лункина. - М. : ИЕ РАН. С. 59-64.

Лункин Р.Н., Филатов С.Б. Межконфессиональные различия в Европе и новые идеологические противостояния. Современная Европа, №3, 2018. С. 102-114.

Партии и движения политической альтернативы в современной Европе. [сб. статей] / отв. ред. В.Я. Швейцер. - М. : Ин-т Европы РАН, 2018. С. 36-54.

Сафонов Д.В., Мельник С.В. Миротворческий потенциал межрелигиозного диалога (на примере участия религиозных лидеров в разрешении Карабахского конфликта). Коммуникология. Том 5, №5, 2017. С. 116-135.

Крюкова Н.В. «У нас неверующих нету!»: отношение к религии в современной Армении. Новые российские гуманитарные исследования, №11, 2016. С. 9.

Наморадзе С. Протестантизм на Кавказе. Кавказ и глобализация. Том: 2, №3, 2008. С. 169180.

Мкоян Г.С. Армянская апостольская церковь, семья и государство как единая система институтов социализации и формирования социально-культурных ценностей в армянском обществе. Общество: социология, психология, педагогика. №5, 2016. С. 28-30.

\section{References}

Evropa XXI veka. Novye vyzovy i riski: [monografiya]; pod obshchej redakciej Al.A. Gromyko, V.P. Fyodorova. - M., SPb.: Nestor-Istoriya, 2017. - 584 s.

Lunkin R. N. Evropejskie cerkvi i demokraticheskie instituty: vozvrashchenie religii ili sekulyarizaciya hristianstva? Vestnik Leningradskogo gosudarstvennogo universiteta imeni A. S. Pushkina. №3, 2016. S. 168-178/

Religioznye missii na obshchestvennoj arene: rossijskij i zarubezhnyj opyt : [kollektivnaya monogr.] / pod red. A.A. Krasikova i R.N. Lunkina. - M.: IE RAN. S. 59-64.

Lunkin R.N., Filatov S.B. Mezhkonfessional'nye razlichiya v Evrope i novye ideologicheskie protivostoyaniya. Sovremennaya Evropa, №3, 2018. S. 102-114.

Partii i dvizheniya politicheskoj al'ternativy v sovremennoj Evrope. [sb. statej] / otv. red. V.Ya. 
Shvejtser]. - M. : In-t Evropy RAN, 2018. S. 36-54.

Safonov D.V., Mel'nik S.V. Mirotvorcheskij potencial mezhreligioznogo dialoga (na primere uchastiya religioznyh liderov v razreshenii Karabahskogo konflikta). Kommunikologiya. Tom 5, №5, 2017. S. 116-135.

Kryukova N.V. «U nas neveruyushchih netu!»: otnoshenie k religii v sovremennoj Armenii. Novye rossijskie gumanitarnye issledovaniya. №11, 2016. S. 9.

Namoradze S. Protestantizm na Kavkaze. Kavkaz i globalizaciya. Tom: 2, №3. 2008. S. 169180.

Mkoyan G.S. Armyanskaya apostol'skaya cerkov', sem'ya i gosudarstvo kak edinaya sistema institutov socializacii i formirovaniya social'no-kul'turnyh cennostej $\mathrm{v}$ armyanskom obshchestve. Obshchestvo: sociologiya, psihologiya, pedagogika. №5, 2016. S. 28-30.

\section{The Position of the Protestant Churches during the Political Crisis in Armenia}

Authors. Roman Lunkin, Senior Fellow in the Institute of Europe, Russian Academy of Sciences, the Head of the Center for Religious Studies in the Institute of Europe, deputy editor-in-chief of the journal «Contemporary Europe». Address: 11-3, Mokhovaya str., Moscow, Russia, 125009. E-mail: romanlunkin@gmail.com.

Abstract. In the article analyzed the role of the protestant churches during the political crisis in Armenia in 2018. The special attention payed to the analysis of the activity of the protestant church of the Pentecostal branch «Word of Life» in a frames of the religious and political studies. The author made a conclusion that the protestant churches of the evangelical movement that rooted on a post-soviet space in 1990s are very active on social and political space in the defending of their interests and in developing of their missionary activity. Among the basic features of the protestant churches in the political life is the claim of their commitment to the patriotism and national interests, the principal standing for the democratic values, the raising of the church members as active citizens, the civil engagement of the believers, he creating of the strategy of the youth mission that suppose the broad involvement of the young people in the development of the civil society, inside non-government organizations and in the political actions.

Key words: Armenia, interreligious dialogue, Christianity, Protestantism, religious legislation, Church-State relations.

DOI: http://dx.doi.org/10.15211/vestnikieran62018182188 